AperTO - Archivio Istituzionale Open Access dell'Università di Torino

\title{
Child and Family Policy in Southern Europe
}

\section{This is a pre print version of the following article:}

Original Citation:

\section{Availability:}

This version is available http://hdl.handle.net/2318/1731933

since 2020-02-27T17:24:49Z

Publisher:

Edward Elgar Publisher

Terms of use:

Open Access

Anyone can freely access the full text of works made available as "Open Access". Works made available under a Creative Commons license can be used according to the terms and conditions of said license. Use of all other works requires consent of the right holder (author or publisher) if not exempted from copyright protection by the applicable law. 


\section{$<$ fresh page $><\mathrm{cn}>16$. $<\mathrm{em}><\mathrm{ct}>$ Child and family policy in Southern Europe <au>Teresa Jurado-Guerrero and Manuela Naldini}

\section{$<a>$ INTRODUCTION}

Comparative research on welfare states has often regarded Southern countries as the more 'familyoriented' or 'familistic' ones (e.g., Esping-Andersen, 1990, 1999). Unlike other countries belonging to Continental welfare regimes (i.e., France, Austria and Germany), or more recently to the Eastern European welfare regime (Saraceno and Keck, 2010), in Southern Europe 'familism' has not translated into state support for families with children. In terms of the 'varieties of familism' (Leitner, 2003), it is difficult to define the relationship between public policies and familism in Southern Europe as supported familism, such as supporting families through parental leave, cash benefits for care or tax relief. Rather, Southern countries may be described as having familism by default or unsupported familism, as the responsibility for providing the care is assigned mainly to the family (women) due to the comparatively low provision of care services and/or government subsidies for families (Saraceno and Keck, 2010).

In the South, the family was and remains the key provider of welfare, a factor which marks a specific way of the functioning of the welfare state (Martin, 1997; Ferrera, 2005; Naldini and Saraceno, 2008). This chapter provides a historical and comparative account of the Southern European family policy model. The chapter is divided into three main sections. We first provide a historical analysis (1980-2014) of the (under)development of family policy in Southern Europe (Greece, Italy, Portugal and Spain) in three main areas: family benefits, Early Childhood Education and Care (ECEC), parental leave and reconciliation policies. We then focus on the Italian and Spanish cases as examples of the model. We attempt to explain the underdevelopment of family policy by looking at the strength of intergenerational ties and kin solidarity, the role of religion, the 
authoritarian past, the strength of unions/left parties and late industrialization. Finally, we discuss what the future of family policies in the Southern countries may look like after the economic crisis.

<a>THE SOUTHERN MODEL OF FAMILY POLICY (1980-2014)

$<\mathrm{b}>$ The Underdevelopment of Family Benefits in a Comparative Perspective

From a comparative and historical perspective, family policies in Southern Europe, since the downfall of various dictatorships, have been characterized by a very fragmented array of measures that are poorly publicaly funded (Bradshaw and Ditch, 1993; Gauthier, 1996; Symeonidou, 1996; Carlos and Alipranti, 2000; Pfenning and Bahle, 2000; Naldini, 2003). In addition, family policies in Southern countries have subsumed child policies, except for pre-school services (3-6), which belong to educational policies. According to Pfenning and Bahle (2000), European family policy models can be clustered historically into five groups. First, there are the Scandinavian countries with child-oriented policies and emphasis on gender equality; second, the English-speaking countries with a liberal, and non-interventionist family policy; third, the Southern countries with weak welfare states and strong kinship, fourth, the French-speaking countries as the European pioneers of family policy with a combination of traditional and progressive elements; and fifth, the German-speaking countries with less developed and more conservative family policies (see also Chapter 2 by Gauthier and Koops and Chapter 4 by Millar on family policy models in this volume).

Southern European countries indeed had the lowest level of public funding for families with children during the 1980s (Bradshaw and Ditch, 1993). From 1990 until 2000, public expenditure on family cash benefits in Spain, Italy and Portugal remained low and without any significant change, except in Greece where a slight increase of expenditure can be observed. In 2000, cash family benefits as a proportion of gross domestic product (GDP) were: 1 per cent in Greece, 0.2 per cent in Spain, 0.5 per cent in Italy and Portugal, compared to 2.1 per cent in Germany, 2 per cent in 
France and an average of 1.4 per cent in the EU-15 (Eurostat, 2003). Italy, Spain and Greece were the only countries in the European Union (EU) without a 'universal' system of family allowances (MISSOC, 2002). These long-term comparisons do not include tax allowances. Fiscal policies are generally very hard to calculate and to compare. It is, however, worth mentioning that Spain introduced in 2002 , for the first time, a tax benefit of $€ 100$ per month for formally employed mothers with children under 3. Since the mid-1990s, national studies for Italy show the increasing importance of tax allowances for children as a policy instrument (Guerra, 2011). The most recent data collected by the Organisation for Economic Co-operation and Development (OECD, 2016a) show that in 2011 Southern countries continued to spend less than the 33 OECD countries' average and that tax allowances do not significantly alter their international ranking position. Cash and tax family benefits in the South as a percentage of GDP are well below the 2.55 per cent OECD average: 1.2 per cent for Spain and Portugal, 1.4 per cent for Greece and 1.5 per cent for Italy. If services for families are included for 2011, then the four countries spent somewhat more: $1.5,1.4$, 1.4 and 2, respectively (OECD, 2016b). In Italy, tax measures accounted for one-quarter of the total public spending on family benefits, a relatively high share for the South.

Since the twenty-first century in Southern Europe cash benefits for households have assumed a selective nature, becoming a measure for fighting family poverty. In some countries this is stronger than in others. Eurostat figures for 2012 show that the EU-29 spent on average 13 per cent of its cash family benefits on means-tested benefits, while in Greece the proportion was 23 per cent, 20 per cent in Spain, 56 per cent in Italy and 63 per cent in Portugal (Eurostat, 2016a). However, despite the greater effort in spending on means-tested family allowances, the capacity of state transfers to reduce the risk of child poverty is comparatively small. In Southern European countries, child poverty rates remain higher than the EU average, amongst others, due to the lower incidence of public transfers (see Figure 16.2; see also Chapter 7 by Bradshaw and Chapter 23 by Gornick and Nell in this volume). 
Southern European welfare states and family policies have traditionally displayed deficits especially in the provision of ECEC, such as childcare facilities for very young children and social services for the frail elderly (Flaquer, 2000). In Southern countries, the lack of childcare services for the youngest children, the inadequacy of most childcare services in terms of quality and time schedules, as well as the low number of part-time jobs make it difficult for dual-earner couples to combine family with work. Dual-earner families with small children have increased in the last decade and represent more than half of the couples with small children (Escobedo and Wall, 2015). The economic crisis has not significantly decreased employment of mothers, but on the contrary in Greece it has grown. As can be seen in Figure 16.1, the enrolment rates in childcare services for children under 3 were very limited in Southern countries in 2000, despite around half of the mothers with small children being employed. Enrolment rates were 3 per cent in Greece, 5 per cent in Spain, 6 per cent in Italy and 12 per cent in Portugal compared to a higer average of 23 per cent for the 16 European countries. Since 2000 childcare coverage for children under 3 has improved in all Southern countries. The increase for Italy and Greece has been less impressive and their current coverage rates are still among the lowest. In contrast, Spain and Portugal have made great improvements and reached levels above the European average. Data reflect children in childcare centres and pre-school formal care arrangements (both public and private) and those who are cared for by liscensed childminders.

\section{< INSERT FIGURE 16.1 HERE >}

In all Southern countries, as in most other European countries, the situation has been better for children between 3/4 and 6 years old, especially where the public services are directly dependent on the Ministry of Education and are free of charge, as in Italy, Spain, Portugal and to some extent Greece (Sims-Schouten, 2000; Eurydice, 2015). In 2014, children aged 3 to 5 years were nearly all 
enrolled in pre-primary schools, except in Greece, where this was the case for 47 per cent of this age group (OECD 2018).

The enrolment rates described can only partly be taken as indicators of the public effort to provide childcare, because each country may offer a wide array of different care arrangements, such as public, publicly supported and non-subsidized private services. For instance, in Spain the data for 2008 and 2014 in Figure 16.1 include public and for-profit formal childcare services. Mostly, parents also have to pay fees for public childcare facilities and may receive public subsidies to pay for private ones, depending on the region. Thus, if one wants to know how much public investment really is, enrolment rates have to be complemented with additional information. Recent data on public expenditure on ECEC for 2012 show that Southern countries invest below the EU average for children under 6: Italy and Spain spend 0.6 per cent of GDP on ECEC followed by Portugal (0.4 per cent), and Greece ( 0.1 per cent), while the average for the 20 European countries is 0.8 per cent (OECD, 2016b: see also Chapter 8 by Rostgaard in this volume).

Thus, in 2014, in Southern Europe most children under 3 continued to be cared for by their parents, relatives or in other informal arrangements. Formal childcare is provided for 17 to 45 per cent of these pre-school children, but public administrations only pay for some of the formal care services and parents have to complement this by paying direct fees. Only from age 3 onwards are most care costs fully funded by public administrations and enrolments reach near universality, except in Greece. In line with these administrative statistics showing a care deficit for the smallest children, different studies show that grandparents, in particular grandmothers, provide more intensive childcare in Southern Europe compared to other European countries (Albertini et al., 2007).

However, erroneous conclusions about public investment in childcare may be drawn if one does not take into account national differences in parental leave regulations. If parental leave and childcare service are taken together, then Portugal, Spain and also Italy show similar coverage rates of children under 3 through a combination of childcare and parental leave; Italy compensates for a 
lower offer of services with a longer paid parental leave. However, considering all childcare policies together, the Southern European countries still may be classed as belonging to an unsupported universal breadwinner model or a male breadwinner model, because the design of parental leave, the offer of childcare services and the level of public payment of these two policies do not provide effective care of children from zero to three years outside the family (Ciccia and Bleijenbergh, 2014).

Parental leave arrangements and flexible working time are crucial policies for the care of small children and their wellbeing in dual-earner families, but great variation exists with respect to duration of leaves, the transferability between parents and the wage replacement level paid during leaves (see also Chapter 11 by den Dulk, Yerkes and Peper in this volume). Southern European countries share a duality between well-paid short maternity and paternity leaves, that is, initial leaves related to childbirth and the care of a newborn, on the one hand, and relatively long but unpaid or low paid parental leaves. As a consequence, the take-up of these leaves is low and strongly gendered, as men hardly use them. In all four countries, the coverage of maternity leaves has been increased to include the self-employed and now basic schemes also cover employed women who previously did not qualify for entitlement. Maternity/initial leaves in 2015 range from three months of leave after childbirth in the Greek public sector to six months in Portugal, if the leave is shared by the father. In addition, fathers' involvement in childcare through specific leaves for fathers is also advancing as non-transferable and well-paid paternity leaves have been partly implemented. In Spain in 2007, a 15-day non-transferable paternity leave was created, which was enlarged to 30 days in 2017 (35 days in 2018), and in Portugal the existing paternity leave increased to 20 days in 2009. In Italy in 2015, a two-day paternity leave was implemented, and in Greece employers grant two days of leave to fathers (Ciccia and Verloo, 2012;Blum et al, 2017).

After these initial leaves, parental leaves to care for small children range from 10/11 months in Italy to 60 months in the Greek public sector (Blum et al., 2017). In addition, they are unpaid (Spain, Portugal and Greece) or low paid (Italy), which prevents men from taking them up. The 
countries producing figures on take-up rates for parental leaves show very low rates for women in Portugal (2.8 per cent) and Spain (7.8 per cent), while they are higher in Italy (54 per cent), because the leave is paid at 30 per cent of the wage level. Men's take-up rates are always well below women's, even in Italy where wage loss is somewhat compensated and a father's bonus was introduced in 2000. Thus, to take full-time parental leave beyond maternity leave is not a mainstream option. This design of well-paid initial/maternity leaves and low or unpaid parental leaves is related to the early return to work of mothers (Escobedo and Wall, 2015).

So, children are mainly cared for by the mother during the first four to six months after childbirth. In some countries, the father can also become involved in early care, but after the first four to six months most couples have to look for care elsewhere, since wage-replacement is very low for full-time parental leave. The latter developments in paternity leaves are the reasons why Southern Europe diverges with respect to the Parental Leave Equality Index (PLEI) (Castro-García and Pazos-Morán, 2016). This index measures the proportion of leave men are likely to use out of the total available in each country and thus indicates their entitlement to care in early childhood. Portugal belongs to those countries that promote co-responsibility, in Spain men are considered to be 'incidental collaborators' in childcare, while Italy and Greece reinforce the traditional gendered division of labour. This gender imbalance in the time for caring in early childhood has consequences for children's attachment to fathers. Fathers involved in care may influence children's wellbeing in many positive ways, as for instance, cognitive development (Sarkadi et al., 2008).

Finally, it should be noted that flexibility in working arrangements can have a considerable impact on reconciliation issues. For many people, especially women, part-time work or the statutory right to reduce working hours provides one important way to combine work and family life. ${ }^{1}$ Southern Europe has been characterized by low levels of part-time work, and part-time jobs are often of low grade, poorly paid, and without long-term career prospects (OECD, 2001). During the Great Recession, from 2008 to 2014, part-time jobs for women increased in all four Southern countries, although there was also an increase in the proportion of involontary part-timers. In 2013, 
33 per cent of female employment in Italy was part time, it was 23 per cent in Spain, while Portugal (14 per cent) and Greece (16 per cent) had lower levels (OECD, 2016). Jobs with flexible working hours were comparativley less common in South European countries (OECD, 2001, table 4.8), whereas this has improved somewhat in the last decade.

To sum up, contrary to the development of family benefits, increasing divergence can be observed in Southern Europe with respect to the development of ECEC for children under 3 and leave policies. Portugal and Spain have expanded childcare services considerably. Leave policies have improved to some extent in Portugal and Italy (length and payment), but only in Portugal and Spain do non-transferable paternity leaves paid at 100 per cent exist.

\section{$<\mathrm{a}>$ HOW CAN THE DEVELOPMENT OF FAMILY POLICIES BE EXPLAINED?}

\section{$<\mathrm{b}>$ Persistence of Underdevelopment until the 1980s}

There are different explanations for the development of family policies in the Southern European region after World War II in each of the decades since World War II, as shown by recent research (Ferragina and Seeleib-Kaiser, 2014), in addition to national-specific traits of polities and welfare state development in each of the countries (Ferrera, 1996). Generally, however, family policies have been underdeveloped. Although the reasons for inadequate family policies are not identical for Italy and Spain, they do have certain similarities. ${ }^{2}$ First of all, in Italy and Spain, the underdevelopment of family policy is a legacy of the previous authoritarian regimes. The Italian fascist experience left strong and widespread opposition to any policy seeming to have pronatalist connotations, including those aimed at supporting the cost of raising children (Saraceno, 1994; Naldini, 2003). The same is true of Spain, where lawmakers avoided family policy-making for a long time after the authoritarian period (Valiente, 1995). 
Second, in Italy and Spain, demands by political parties for social policy for families with children have been further constrained by ideological divisions over which family model the state should support. Left-wing parties in these countries avoided including family and social policy for children on the political agenda, framing instead requests in terms of social rights for women and individual rights (Naldini, 2000). Also, the trade unions in South European countries remained male-dominated and had no interest in putting family policy demands on the agenda for a long time (Andreotti et al., 2001).

Third, the generally late and qualitatively varied form of modernization in Southern Europe has affected women's accession to the labour market. Most ECEC programmes in the rest of Europe were developed in response to women's access to the labour market. In Southern Europe, protracted periods of high unemployment and a sizeable informal economy contributed to making women the main providers of informal care and the key actors in promoting intergenerational solidarity. The continuing predominance of self-employment and small family enterprises was also significant, particularly insofar as they are a considerable source of employment for women and other family members (Andreotti et al., 2001; Karamessini, 2006). These types of jobs allow women to continue to provide care at home, since the boundaries between family and work are often blurred in family businesses.

Fourth, the latecomers to democracy had to invest a lot of resources in the consolidation of social security income-support benefits (mainly pensions), and in the creation of universal health and education services. Electoral speeches by politicians across parties were typically devoted to issues such as wage increases, unemployment benefits and social security rights, rather than to family issues, despite the very low fertility rates reported from the 1980s. In contrast to countries such as France, which responded to the fertility decline by implementing explicit pronatalist policies, Southern Europe omitted the problem from the political agenda until the 1990s. In Spain, recurrent unemployment and the coming of age of the large baby-boom generation of the 1980s and 
1990s prevented politicians and voters from perceiving fertility decline as a social problem (Garrido and Malo, 2005).

Fifth, in both Italy and Spain the Church exercised a strong cultural hegemony on family definition and family issues. In particular, the Catholic social doctrine played a role in shaping the welfare state in Southern Europe (Castles, 1994). The Catholic Church and the Orthodox Church in Greece have continued to emphasize, for instance, the principle of 'subsidiarity', which means that priority is given to smaller and voluntary organizations over the state, whenever possible. This had a negative influence for a long time on the development of public childcare services, kindergartens and services for the elderly. It has also shaped the way in which these two welfare states have developed poor relief scheme (Naldini, 2003).

Finally, the strength of intergenerational ties and kin solidarity was based on the enduring norms of 'rural' society and patriarchal relationships. Family solidarity has bridged the functional gap created by late and limited provision of social protection and care services by the state (Naldini, 2003). In turn, this has a reciprocal influence on social policy development, insofar as both the intra-family pooling of resources and intergenerational redistribution have probably reduced the social and electoral pressure for further expanding the welfare state. Similarly, structural unemployment among the young, and the strength of family businesses, segmented labour markets and the informal economy have contributed to the strengthening of family and kinship solidarity networks (García and Karakatsanis, 2006). A broad set of social and economic relationships are linked within a reinforcing spiral where cause and effect are interwoven.

\section{$<\mathrm{b}>$ New Family Challenges and New Policy Drivers from the 1990s Onwards}

The historical reasons for the underdevelopment of family policy are, however, growing less importance and some new family policies are being unfolded. In the last two decades the institutional dimension of the family has been exposed to great change in Southern Europe. The 
biggest challenges are the very profound demographic and social changes affecting Southern European families. Family support and especially intergenerational solidarity may not have decreased as a value system, but family help will no longer suffice to cope with the 'care deficit' these societies are experiencing. In Italy and Spain very low fertility patterns and, in particular, the very low proportions of households with three or more children are some of the results of a sharp increase in the number of highly educated women and of uninterrupted female careers. These trends have not been offset by a supportive context for combining family commitments and employment, something which Esping-Andersen (2009) labels as the incomplete revolution. Male participation in care and domestic tasks remains low, and public policies in support of the family and the reconciliation of paid and unpaid work are insufficient. Given that many more mothers in Southern Europe now carry a double burden, the limitation of the number of children is a rational individual strategy to combine work and family duties.

Marriage in Spain and (to a limited extent) in Italy has undergone a process of deinstitutionalization (Cherlin, 2004). Crude marriage rates have declined all over OECD countries but this decline has been especially acute in South Europe. More generally, cohabitation as an alternative to marriage has become much more widespread especially in Portugal and Spain (Domínguez and Castro, 2013), as is the case in other South European countries. In general, changes for women and family, both in society and in social policies, have been much more profound in Spain than in Italy (Naldini and Jurado, 2013). Since the 1990s, Spain has changed in the direction of Nordic countries by increasing the share of dual-earner households, which has stagnated at lower levels in Italy in the last decade. Spain has been praised for its public commitment to gender equality, which symbolically achieved important results in April 2004 with the first gender-parity government in Spanish history. Not only have family values and the reality of family changed in Spain, but also the legal definitions of family relations and public policies have followed a slightly different trajectory to that in Italy, characterized by 'a quasi frozen landscape' (Palier and Martin, 2008; Naldini and Saraceno, 2008; León and Pavolini, 2014). Despite low 
family benefits, Spain has increased public childcare services steadily and rapidly, as described above. A number of scholars have attributed the different Spanish welfare expansion to being a latecomer, which turned out to be a comparative advantage compared to Italy (Guillén and León, 2011; León and Migliavacca, 2013; León and Pavolini, 2013). However, this explanation is not sufficient, because countries such as Germany, which did not need to catch up, have also introduced reforms in family/care policies.

Why then did Italy not change ECEC like Spain or achieve similar gender-parity objectives? Again, a region-specific answer might emphasize the role of the Catholic Church in Italy. One can argue that the veto power of the Vatican has always been much stronger in Italy than in Spain. In Italy, a stronger cultural hegemony exercised by the Catholic Church on family issues has for a long time hindered any suggestion of alternative definitions, and delayed reforms,e.g. not acknowledging the diversity of family forms; the divorce law changed only in 2014; the family name is taken only from the father; and only a two-day paternity leave was introduced in Italy in 2012 (Musumeci et al., 2015). However, this kind of explanation does not lend itself to generalization.

In recent studies examining the political factors affecting the coverage and spending rates on childcare, some authors point to the importance of the percentage of women in the parliament (Bonoli and Reber, 2010), while studies on childcare and parental leave policies emphasize the causal importance of party competition over female votes and electorate preferences on such policies at least until the 1990s (Morgan, 2013; Ferragina and Seeleib-Kaiser, 2015). Morgan (2013) provides an attractive causal argument for explaining the expansion of work-family policies in several European countries by using the electoral competition thesis. The expansion of workfamily policies in Germany and Britain is seen as a way for political parties to appeal to female voters. This has indeed also occurred in Spain, where the socialists (PSOE) and the conservatives (PP) have both targeted women, and for some time, 1989-2008, the former has attracted more female votes (Calvo and Martín, 2009). Interestingly, the electoral competition and the provisions of the 2007 equality law have also increased the number of female politicians in Spain (36 per cent 
of deputees in the parliament from 2008-15 and 39 per cent in 2016). By the same token, the lack of electoral competition around female voters in Italy has impeded the advancement of women in politics and the entrance on the political agenda of issues related to care and support of women's employment (Estevez-Abe and Naldini, 2016). Though, as some scholars argue, Italy's childcare landscape does not mean that there were no efforts or any legislative initiatives to expand childcare during the last two decades. On the contrary, since the 1990s there have been numerous legislative initiatives and attempts at all levels of the government - including initiatives at regional and local levels in what has been labelled as a process of 'modernization from below' (Ferrera and Maino, 2014; Léon and Pavolini, 2014; Olivier and Matzke, 2014). However, the services enacted by regional and local authorities have not been sufficient to produce any clear shifts in favour of a general expansion of childcare services and defamilization of care (Estevez-Abe and Naldini, 2016). In a comparative study including Italy and other non-Southern European countries the researchers concluded that since the 2000s partisanship and socio-economic factors have become less important as drivers of changes in family policies, while cultural change as indicated by preferences of urban women for gender equality and employment-oriented family policy may push political parties to new agendas. In addition, family policy expansion may also have a positive feedback effect on public opinion pushing for these sort of policies (Ferragina and Seeleib-Kaiser, 2015).

\section{$<$ a POST-ECONOMIC CRISIS SCENARIO}

The Great Recession of 2008-14 hit South European countries very strongly. Male and female unemployment rates rose and, as a consequence, in Italy, Spain, Greece and Portugal the proportion of children aged 0-17 living in jobless households increased from around 4-6 per cent in 2007 to 10-14 per cent in 2013 (Eurostat, 2016b). Unemployment benefits mitigated parents’ unemployment at the beginning of the crisis to a large extent, but long-term unemployment (longer than one year) later began to affect increasing proportions of the active population throughout the 
South, in particular in Greece (20 per cent) and Spain (13 per cent), and less so in Portugal and Italy (7 per cent). The strong impact of unemployment in Greece and Spain was alleviated by increasing female labour activity rates during the Great Recession: Greek and Spanish women aged 25 to 54 increased their activity rates from around 70 per cent in 2007 to 75 per cent and 82 per cent, respectively, in 2014, approaching the Portuguese rate (86 per cent) and leaving behind the Italian rate (66 per cent) (Eurostat, 2016c). Increasing female labour force activity and the pooling of resources within larger households mitigated income inequalities to some extent in Greece and Spain (Hellebrandt, 2014). However, these family efforts, in the absence of more generous public transfers, have not prevented the relative growth of child poverty rates in most of Southern Europe.

\section{<INSERT FIGURE 16.2 HERE >}

As can be seen in Figure 16.2, the rates of children under 18 at risk of poverty after social transfers were already higher in Southern European welfare states compared to France and Germany in 2007. The crisis increased the relative poverty rates of children in most Southern countries and social transfers are comparatively less able to mitigate them. In 2014, poverty rates in Southern Europe after social transfers continued to be at a higher level, between 25 and 33 per cent than in France, Germany and the UK, where they range from 15 to 20 per cent, despite the fact that in these countries the market also produces very high poverty rates. Thus, after the crisis the low capacity of the welfare states in the South to tackle child poverty persists or even worsens.

With respect to parental leave and ECEC, the crisis has not changed entitlements or enrolment rates, but has prevented enlargement of some crucial polices. In Spain, paternity leave has become a victim of the crisis, since it should have been increased from two to four weeks in January 2011, but this has been postponed for the time being for cost savings reasons. The increasing female activity rates in Spain and Greece may help to understand why enrolment rates in day care centres increased or at least remained stable throughout the Great Recession of 2008. 


\section{$<\mathrm{a}>$ CONCLUSIONS}

Family policy constitutes a wide domain of public intervention and includes many policy instruments (Gauthier, 1999; Pfenning and Bahle, 2000). Family policy as a field of intervention has had a multivalent character and variable outcomes and it developed during the twentieth century for reasons which vary according to country, to historical periods and to the policy field analysed (Gauthier, 1996). Most importantly, family policies have had and still have a multiplicity of purposes (to increase fertility, to reduce child poverty, to promote gender equality, to achieve horizontal redistribution and so son). In the last two decades, even during the era of austerity, family policies have expanded in most European countries to varying degrees (Morgan, 2013; Ferragina and Seeleib-Kaiser, 2015). There has been a readjustment of old welfare programmes and the expansion of programmes for 'new social risks' (Morel et al., 2012). This often meant the expansion of those family policies which aim to support maternal employment and enhance ECEC policies, even in countries characterized as a 'strong male breadwinner' type, such as Germany and the UK (Morgan, 2013).

This chapter has shown that since the 1980s family policies in Southern Europe have changed to some extent, but the overall picture remains the one featured at the beginning of this chapter: weak development of family policies in a context of important 'unsupported familism'. Family policies in Southern Europe have changed somewhat in relation to services and time but to a lesser degree in relation to family benefits. Employment-related family policies have expanded, though differently across Southern countries, as shown by the increase of enrolment rates of small children in day care services and by a new paternity or father's bonus in parental leave in recent years. However, family allowances or tax breaks for families are still less generous than in Continental, Anglo-Saxon and Northern Europe, which to a large extent explains the higher relative poverty rates among children in the South. In addition, despite the expansion of ECEC, Southern countries 
still receive less public funding than in Nordic and some Continental welfare states, and in comparison to these countries well-paid parental leave is in general shorter too. Thus, altogether in Southern Europe in 2016 family policies as a policy package were still less developed and less generous than in other European welfare states. We explored in the chapter whether this is only a question of lagging behind and whether Southern countries need more time to develop generous policies for children and a stronger orientation of policies towards female employment. This is not a good explanation, however, because Spain, being a laggard compared to Italy, has achieved more changes in the last decade than the latter. Both countries share similar demographic challenges of a very low fertility rate and rapidly ageing population, but Spain has advanced more on the way to reconciling employment and family. We have interpreted these divergent paths to be caused by political party competition for female voters in Spain in contrast to Italy, by diverging female employment patterns, and the resulting pressures for more employment-oriented family policies.

Future developments in Southern Europe may depend, first, on the evolution of public opinion about how to reconcile employment and family life without compromising equal opportunities for women and men. Second, the way the fiscal crisis is to be resolved will also be essential for the future generosity of family policies and child wellbeing. Finally, all Southern countries will have to face care deficit issues in the near future, given the phenomena of women's increasing participation in the workforce, the ageing of societies and the rising age of retirement,. In this respect, more childcare-oriented policies to support working parents are not only measures aiming at gender equality but are also crucial for social investment and for reducing child poverty, which is dramatically high in the Southern countries.

\section{$<a>$ NOTES}

1. In Portugal, Greece and Spain a statutory right to reduce working hours until a given age of the child exists (for more see Blume et al., 2017).

2. In this section we only focus on Italy and Spain. 
<single line sp.> 
$<$ a $>$ REFERENCES

Albertini, M., M. Kohli, and C. Vogel (2007), 'Intergenerational transfers of time and money in European families: common patterns - different regimes?', Journal of European Social Policy, 17 (4), 319-34.

Andreotti, A., S. Marisol Garcia, A. Gomez, P. Hespanha, Y. Kazepov, and E. Mingione (2001), 'Does a Southern European model exist?', Journal of European Area Studies, 9 (1), $43-62$.

Blum, S., Koslowski, A., and Moss, P. (Eds.). (2017). 13th International Review of Leave Policies and Related Research 2016. International Network on Leave Policies and Related Research (http://www.leavenetwork.org/lp_and_r_reports/review_2017/, accessed July 2018).

Bonoli, G. and F. Reber (2010), 'The political economy of childcare in OECD countries: explaining cross-national variations in spending and coverage rates', European Journal of Political Research, 49, 97-118.

Bradshaw, J. and J. Ditch (1993), Support for Children. A Comparison of Arrangements in Fifteen Countries, Research Report, 21, London: HMSO.

Calvo, K. and I. Martín (2009), ‘Ungrateful citizens? Women’s rights policies in Zapatero’s Spain', South European Society and Politics, 14 (4), 487-502.

Carlos, M. and L. Maratou-Alipranti (2000), 'Family policy and new family forms: the cases of Greece and Portugal', in A. Pfenning and T. Bahle (eds), Families and Family Policies in Europe: Comparative Perspective, Frankfurt am Main: Peter Lang Verlag der Wissenschaften, pp. 34-49.

Castles, F.G. (1994) 'On religion and public policy: does Catholicism make a difference', European Journal of Political Research, 25 (1), 19-40.

Castro-García, C. and M. Pazos-Morán (2016), 'Parental leave policy and gender equality in Europe', Feminist Economics, 22 (3), 1-23.

Cherlin Andrew, J. (2004), 'The deinstitutionalization of American marriage', Journal of Marriage and Family, 66 (4), 848-61.

Ciccia, R. and I. Bleijenbergh (2014), 'After the male breadwinner model? Childcare services and the division of labor in European countries', Social Politics: International Studies in Gender, State \& Society, 21 (1), 50-79.

Ciccia, R. and M. Verloo (2012), 'Parental leave regulations and the persistence of the male breadwinner model: using fuzzy-set ideal type analysis to assess gender equality in an enlarged Europe', Journal of European Social Policy, 22 (5), 507-28. 
Domínguez Folgueras, M. and T. Castro Martin (2013), 'Cohabitation in Spain: no longer a marginal path to family formation', Journal of Marriage and Family, 75 (2), 422-37.

Escobedo, A. and K. Wall (2015), 'Leave policies in Southern Europe: continuities and changes', Community, Work \& Family, 18 (2), 218-35.

Esping-Andersen, G. (1990), The Three Worlds of Welfare Capitalism, New York: Polity Press. Esping- Andersen, G. (ed.) (1999), Social Foundations of Postindustrial Economies, Oxford:

Oxford University Press.

Esping-Andersen, G. (2009), Incomplete Revolution: Adapting Welfare States to Women's New Roles, Cambridge: Polity Press.

Estevez-Abe, M. and M. Naldini (2016), 'Politics of defamilialization: a comparison of Italy, Japan Korea and Spain', Journal of Social Policy, 26 (4), 327-43.

Eurostat (2003), 'Social protection: cash family benefits in Europe', Statistics in Focus. Population and Social Conditions, theme 3, 19, Luxembourg.

Eurostat (2016a), 'Social protection expenditure (spr_exp_ffa)', accessed October 2016 at http://ec.europa.eu/eurostat/web/social-protection/data/database.

Eurostat (2016b), 'Employment and labour market statistics (Ifsi_jhh_a)', accessed June 2016 at http://ec.europa.eu/eurostat/web/lfs/data/database

Eurostat (2016c), 'Employment and labour market statistics (lfsi_act_a)', accessed June 2016 at http://ec.europa.eu/eurostat/web/lfs/data/database

Eurostat (2016d), 'Living conditions (ilc_caindformal)', accessed May 2016 at http://ec.europa.eu/eurostat/web/income-and-living-conditions/data/database

Eurydice (2015), ‘Greece. Organisation of programmes for children under 4 years', accessed June 2016 at https://webgate.ec.europa.eu/fpfis/mwikis/eurydice/index.php/Main_Page.

Ferragina, E. and M. Seeleib-Kaiser (2015), 'Determinants of a silent (r)evolution: understanding the expansion of family policy in rich OECD countries', Social Politics, 22 (1), 1-37.

Ferrera, M. (1996), 'The'Southern model'of welfare in social Europe', Journal of European Social Policy, 6 (1), 17-37

Ferrera, M. (ed.) (2005), Welfare States and Social Safety Nets in Southern Europe, London: Routledge.

Ferrera, M. and F. Maino (2014), 'Social innovation beyond the state. Italy's second welfare in a European perspective', Working Papers Secondo Welfare, 2/2014, accessed October 2016 at http://www.secondowelfare.it/allegati/ferrera_maino_wp2_2014_2wel.pdf. 
Flaquer, L. (2000), 'Is there a Southern European model of family policy?', in A. Pfenning and T. Bahle (eds), Families and Family Policies in Europe, Frankfurt am Main: Peter Lang Verlag der Wissenschaften, pp. 15-33.

García, M. and N. Karakatsanis (2006), 'Social policy, democracy, and citizenship in Southern Europe', in R. Gunther, P.N. Diamandouros, and D.A. Sotiropoulos (eds), Democracy and the State in the New Southern Europe, New York: Oxford University Press, pp. 87-137.

Garrido, L. and M.A. Malo (2005), 'Postponement of family formation and public budget: another approach to very low fertility in Spain', Public Finance and Management, 5 (1), 152-77.

Gauthier, A.H. (ed.) (1996), The State and the Family: A Comparative Analysis of Family Policies in Industrialised Countries, New York: Oxford University Press.

Gauthier, A.H. (1999), 'Family change: practices, policies and values', The Sources and Methods of Comparative Family Research in Comparative Social Research, 18, 31-56.

Guerra, M.C. (ed.) (2011), 'Fisco e welfare per le famiglie, in Ascoli, U', in Il welfare in Italia, Bologna: Mulino, pp. 225-55.

Guillén, A.M. and M. León (2011), The Spanish Welfare State in European Context, Aldershot: Ashgate.

Hellebrandt, T. (2014), Income Inequality Developments in the Great Recession, LIS Working Paper Series, No. 604, Luxembourg Income Study.

Karamessini, M. (2006), 'Gender equality and employment policy', in M. Petmesidou and E. Mossialos (eds), Social Policy Developments in Greece, Aldershot: Ashgate, pp. 239-265.

Leitner, S. (2003), 'Varieties of familialism. The caring function of the family in comparative perspective', European Societies, 5 (4), 353-75.

León, M. and M. Migliavacca (2013), 'Italy and Spain: still the case of familistic welfare models?', Population Review, 52 (1), 25-42.

León, M. and E. Pavolini (2013), 'Cross national variations in care and care as a labour market', in M. León (ed.), The Transformations of Care in European Societies, Houndmills, Basingstoke: Palgrave Macmillan, pp. 34-61.

León, M. and E. Pavolini (2014), 'Social investment or back to familism: the impact of the economic crisis on care policies in Italy and Spain', South European Society \& Politics, 19 (3), 353-69.

Martin, C. (1997), 'Social welfare and the family in Southern Europe: are there any specificities?', Mire Florence Conference, Comparing Social Welfare Systems in Southern Europe, Vol. 3, Paris: Mire, pp. 315-35. 
MISSOC (2002), 'Mutual information system on social protection', Social Protection in the EU Member States and the European Economic Area, Situation on 1 January 2001.

Morel, N., B. Palier, and J. Palme (eds) (2012), Towards a Social Investment Welfare State? Ideas, Policies and Challenges, Bristol: Policy Press.

Morgan, K.J. (2013), 'Path shifting of the welfare state electoral competition and the expansion of work-family policies in Western Europe', World Politics, 65 (1), 73-115.

Musumeci, R., M. Naldini, and A. Santero (2015), 'First-time fathers and child care. Persistence and innovation in the Italian fatherhood regime', Interdisciplinary Journal of Family Studies, $1,1-19$.

Naldini, M. (2000), 'Family allowances in Italy and Spain, long ways to reform', in A. Pfenning and T. Bahle (eds), Families and Family Policies in Europe: Comparative Perspective, Frankfurt am Main: Peter Lang, pp.70-89.

Naldini, M. (ed.) (2003), Family in the Mediterranean Welfare States, London: Frank Cass.

Naldini, M. and C. Saraceno (2008), 'Social and family policies in Italy: not totally frozen but far from structured reforms', Social Policy \& Administration, 42 (7), 733-53.

Naldini, M. and T. Jurado-Guerrero (2013), 'Family and welfare state reorientation in Spain and inertia in Italy', Population Review, 54 (1), 43-61.

OECD (2001), 'Balancing work and family life; helping parents into paid employment, Employment Outlook. http://www.oecd.org/social/family/2079435.pdf

OECD (2016a), Social Expenditure Database, accessed October 2016 at http://www.oecd.org/social/expenditure.htm.

OECD (2016b), OECD Family Database, accessed October 2016 at http://www.oecd.org/els/family/database.htm

OECD (2018), OECD Family Database, PF.3.2, Enrolement 0-2, accessed July 2018 at http://www.oecd.org/els/soc/PF3_2_Enrolment_childcare_preschool.xlsx

Oliver, R. J. and Mätzke, M. (2014) "Childcare Expansion in Conservative Welfare States: Policy Legacies and the Politics of Decentralized Implementation in Germany and Italy." Social Politics 21(2):167-193.

Palier, B., and Martin, C. (eds.) (2008), Reforming the Bismarckian welfare systems. John Wiley \& Sons.

Pfenning, A. and T. Bahle (eds) (2000), Families and Family Policies in Europe, Frankfurt am Main: Peter Lang.

Saraceno, C. (1994), 'The ambivalent familism of the Italian welfare state', Social Politics, 1 (Spring), 60-82. 
Saraceno, C. and W. Keck (2010), 'Can we identify intergenerational policy regimes in Europe?', European Societies, 12 (5), 675-96.

Sarkadi, A., R. Kristiansson, F. Oberklaid, and S. Bremberg (2008), 'Fathers' involvement and children's developmental outcomes: a systematic review of longitudinal studies', Acta paediatrica, 97 (2), 153-8.

Sims-Schouten, W. (2000), 'Child care services and parents' attitudes in England, Finland and Greece', in A. Pfenning and T. Bahle (eds), Families and Family Policies in Europe: Comparative Perspectives, Frankfurt and New York: Peter Lang International Academic Publishers, pp. 270-89.

Symeonidou, H. (1996), 'Social protection in contemporary Greece', South European Society \& Politics, 1 (3), 67-86.

Valiente, C. (1995), 'Children first: central government child care policies in post-authoritarian Spain (1975-1994)', in J. Brannen and M. O'Brien (eds), Childhood and Parenthood, London: Institute of Education, University of London, pp. 249-66. 